\title{
Exceptionally preserved 'skin' in an Early Cretaceous fish from Colombia
}

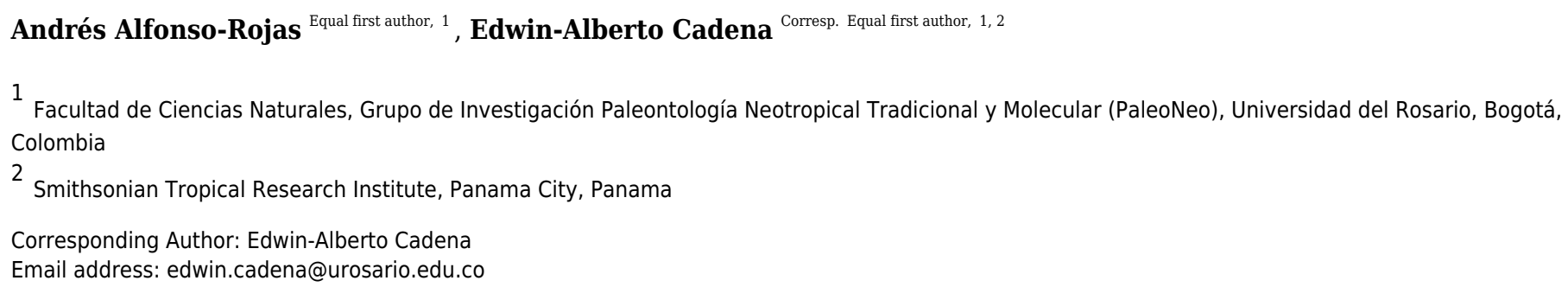

Studies of soft tissue, cells and original biomolecular constituents preserved in fossil vertebrates have increased notoriously in recent years. Here we report preservation of 'skin' with chemical and molecular characterization from a three-dimensionally preserved caudal portion of an aspidorhynchid Cretaceous fish from the equatorial Barremian of Colombia increasing the number of localities for which exceptional preservation is known. We applied several analytical techniques including SEM-EDS, FTIR and ToF-SIMS to characterize the micromorphology and molecular and elemental composition of this fossil. Here, we show that the fossilized 'skin' exhibits similarities with those from extant fish including the wrinkles after suffering compression stress and flexibility, as well as architectural and tissue aspects of the two main layers (epidermis and dermis). This similarity extends also to molecular level, with the demonstrated preservation of potential residues of original proteins not consistent with bacterial source. Our results show a potential preservation mechanism where scales may have acted as an external barrier and together with an internal phosphate layer resulting from the degradation of the dermis itself creating an encapsulated environment for the integument. 
1 Exceptionally preserved 'skin' in an Early Cretaceous fish 2 from Colombia

3

4

5

6

7

8

\author{
Andrés F. Alfonso-Rojas ${ }^{1}$; Edwin-Alberto Cadena ${ }^{1,2}$
}

${ }^{1}$ Facultad de Ciencias Naturales, Grupo de Investigación Paleontología Neotropical Tradicional y Molecular (PaleoNeo), Universidad del Rosario, Bogotá, Colombia

${ }^{2}$ Smithsonian Tropical Research Institute, Panama City, Panama

Corresponding Author:

Edwin-Alberto Cadena ${ }^{1}$

Cra 26 63b-48, Bogotá, 111221, Colombia

Email address: edwin.cadena@urosario.edu.co

\title{
Abstract
}

Studies of soft tissue, cells and original biomolecular constituents preserved in fossil vertebrates have increased notoriously in recent years. Here we report preservation of 'skin' with chemical and molecular characterization from a three-dimensionally preserved caudal portion of an aspidorhynchid Cretaceous fish from the equatorial Barremian of Colombia increasing the number of localities for which exceptional preservation is known. We applied several analytical techniques including SEM-EDS, FTIR and ToF-SIMS to characterize the micromorphology and molecular and elemental composition of this fossil. Here, we show that the fossilized 'skin' exhibits similarities with those from extant fish including the wrinkles after suffering compression stress and flexibility, as well as architectural and tissue aspects of the two main layers (epidermis and dermis). This similarity extends also to molecular level, with the demonstrated preservation of potential residues of original proteins not consistent with bacterial source. Our results show a potential preservation mechanism where scales may have acted as an external barrier and together with an internal phosphate layer resulting from the degradation of the dermis itself creating an encapsulated environment for the integument.

\section{Introduction}

Exceptional preservation in the fossil record is expressed in a wide range of structures including hair, cells, blood vessels, claw sheaths, feathers, pycnofibers, muscle remains, skin and even the potential remains of original biomolecular constituents (DNA, proteins, lipids) (Lingham-Soliar \& Plodowski 2010; Cadena 2016; Cadena \& Schweitzer 2012; Cleland et al. 2015; McNamara et al. 2018a; Schweitzer 2011; Wiemann et al. 2018; Bailleul et al., 2020) associated with these structures. The skin is the largest organ of a vertebrate body, which encloses or covers their entire body. Numerous integumentary derivatives are located within the epithelial sheet itself (glands) or extend above its 
40 surface (teeth, scales, feathers, hairs, etc.) (Chernova 2009). The skin of vertebrates and its derivate

41 structures has been shown to have high preservation potential in the fossil record, and has been reported

42 in dinosaurs, pterosaurs, snakes, frogs and birds (McNamara et al. 2018a; McNamara et al. 2016;

43 McNamara et al. 2009; McNamara et al. 2018b; Varejão et al. 2019). Similarly, fishes are also covered

44 by a relatively flexible skin, which in almost all extant and extinct groups is associated with hard scales

45 comprised of collagen I, calcium salts (Sionkowska \& Kozlowska 2014), ganoine and cosmine.

46 Preservation of skin in fossil fish has been documented in many Konservat Lagerstätte sites, including

47 the Messel Formation, Germany (Micklich 2002), Huajiying and Yixian formations (Xu et al. 2020);

48 and Romualdo Formation (previously Santana Formation) of northeastern Brazil (Kellner et al. 2013;

49 Maisey 1991; Martill 2007) (Fig. 1D).

50

Despite the abundant recent discoveries of fossil vertebrates from the Cretaceous of Colombia (Cadena 2015; Cadena \& Parham 2015; Cadena et al. 2019; Carballido et al. 2015; Maxwell et al. 2019; PáramoFonseca et al. 2016; Vernygora et al. 2018), the exceptional preservation of soft tissue or their potential original components is still rarely reported for most of them, with the exception of the recently described gravid marine turtle from the Early Cretaceous of Villa de Leyva (Cadena et al. 2019). Here we report a caudal fragment of an aspidorhynchid fossil fish recovered from the lower segment of the Paja Formation from Zapatoca, Santander, Colombia (Fig. 1A-C) which constitutes the first specimen of the paleontological collection at Universidad del Rosario in Bogotá. We have applied multiple analytical techniques to interrogate the degree of preservation of its skin, including some of their potentially original biomolecular constituents. Our finding not only expands the worldwide record of skin preserved in Cretaceous vertebrates, but also constitutes the most equatorial example of it (Fig. 1D) considering that Colombia has barely changed its latitude since the Early Cretaceous (Fig. S1).

\section{Materials \& Methods}

Fossil material Collection and Geological framework. UR-CP-0001 specimen was collected by E-A. Cadena in 2016, during a short expedition to Zapatoca. The fossil was found approximately $100 \mathrm{~m}$ north-west from the Radio Lenguerke station antenna region, Zapalonga locality $\left(6^{\circ} 48^{\prime} 28.94^{\prime}\right.$ ' $N$, abundant occurrence of large concretions and interbedded layers of fossiliferous limestones (Fig. 1B). This sequence represents the most basal member of the Paja Formation in this zone, a few meters above the last limestone bank of the underlying Rosablanca Formation. Approximately 35 meters of stratigraphic column were measured and described (Fig. 1C).

The fossil was collected using sterile nitrile gloves and wrapped in aluminum foil, and placed in a plastic bag with silica gel small packets to controlled humidity. To avoid any contamination, the fossil has not been treated mechanically or chemically and always has been manipulated using sterile nitrile gloves for measurements, photographing or sampling for analytical studies. Fieldwork and laboratory 
79

80

81

82

83

84

85

86

87

88

89

90

91

92

93

94

95

96

97

98

99

100

101

102

103

104

105

106

107

108

109

110

111

112

113

114

115

116

117

118

experiments permit granted by the Comité de ética and the Dirección de Investigaciones of the Universidad del Rosario (IV-FCS018).

Institutional abbreviation. UR-CP; paleontological collection, Facultad de Ciencias Naturales y Matemáticas, Universidad del Rosario, Bogotá, Colombia.

Specimen photography, internal observation and measurements. General views of UR-CP-0001 specimen were obtained using a Leica-EZ4-HD and Nikon SMZ1270 stereomicroscopes coupled with cameras. Measurements of the specimen were obtained using a caliper, always wearing nitrile gloves during its manipulation. The specimen was scanned using computer tomography (CT-scan), Toshiba Aquilion at the Radiology unit of Hospital Méderi, Bogotá, with the following setup parameters: voltage $120 \mathrm{kV}$, exposure $225 \mathrm{mAs}$, and voxel size $350 \mu \mathrm{m}$.

Transmitted and polarized light microscopy. In order to observe and obtain microscopic details of the preserved 'skin', small pieces of approximately $5 \mathrm{~mm}^{3}$ each were sampled and treated separated with $\mathrm{HCl} 25 \%$ for 24 hours and EDTA $0.5 \mathrm{M} \mathrm{pH} 8.0$ for 4 days changing daily to dissolve carbonate matrix and full demineralization. The isolated remains of 'skin' were rinsed 3 times with E-Pure water to remove $\mathrm{HCl}$ and EDTA, then were mounted in glass slides, observed and photographed using a Nikon ECLIPSE-80i transmitted-light microscope and an Olympus CX-31 polarized microscope. Samples were finally transferred to sterilized containers for Fourier-transform infrared spectroscopy (FTIR) analyses.

FTIR spectroscopy. Samples from an extant Orechromis sp. (Mojarra fish), and four samples from the UR-CP-0001 fossil fish ('skin' from HCl, EDTA treatments, 'skin' untreated and infilling matrix) were analyzed. The FTIR spectra were collected in the mid-infrared range of $4000-600 \mathrm{~cm}^{-1}$ wavelength using a Bruker Optics - ALPHA ZnSe FTIR spectrometer at the Biomedical Engineering Lab of Universidad de los Andes, Bogotá, Colombia. Between each analysis, the crystal and sample holder of the spectrometer were cleaned up with isopropanol and standardized with an "air" measurement in order to reduce rovibration absorptions of carbon dioxide present in the ambient air. Measurements were repeated twice for each of the samples. For the 'skin' untreated spectrum a deconvolution was performed for the 1450-1800 $\mathrm{cm}^{-1}$ range in order to find out the specific peaks associated to the vibrational band frequencies of Amide I and II, similar as described in Kong \& Yu (2007).

\section{Scanning electron microscopy and elemental analysis (SEM-EDS). Four different regions of the} fossil fish were sampled for Scanning Electron Microscope (SEM)-coupled with Energy Dispersive XRay Spectroscopy (EDS) observation and characterization, taking $\sim 5 \mathrm{~mm}^{3}$ of each (scale 'skin', and two different regions of the infilling matrix exhibiting different coloration). Samples were mounted in sterile carbon stubs and storage in sterile boxes prior to the SEM-EDS analyses, which were performed at the Microscopy Core Facility of Universidad de los Andes, Bogotá, Colombia. Samples were analyzed without adding any coating. Imaging and map elemental composition were obtained at $10 \mathrm{kV}$ using a 
119 JEOL-JSM-6490 LV SEM, while the point elemental composition was performed at $10 \mathrm{kV}$ using a 120 TESCAN-Lyra3 SEM.

121

122

123

124

125

126

127

128

129

130

131

132

133

134

135

136

137

138

139

140

141

142

143

144

145

146

147

148

149

150

151

152

153

154

155

156

157

158

Time of Flight Secondary Ions Mass Spectrometry (ToF-SIMS). Two samples from the UR-CP0001, an untreated (fresh) and an $\mathrm{HCl}$ treated were mounted in sterilized glass and sent to the Analytical Instrumentation Facility (AIF) of North Carolina State University, Raleigh, North Carolina. ToF-SIMS analyses were conducted using a TOF SIMS V (ION TOF, Inc. Chestnut Ridge, NY) instrument equipped with a $\mathrm{Bi}_{n}{ }^{m+}(\mathrm{n}=1-5, m=1,2)$ liquid metal ion gun, $\mathrm{Cs}^{+}$sputtering gun and electron flood gun for charge compensation. Both the $\mathrm{Bi}$ and $\mathrm{Cs}$ ion columns are oriented at $45^{\circ}$ with respect to the sample surface normal, with at least two different regions of the sample being analyzed. The instrument vacuum system consists of a load lock for rapid sample loading and an analysis chamber, separated by the gate valve. The analysis chamber pressure is maintained below $5.0 \times 10^{-9}$ mbar to avoid contamination of the surfaces to be analyzed.

For high mass resolution spectra acquired in this study, a pulsed $\mathrm{Bi}_{3}{ }^{+}$primary ion beam at $25 \mathrm{keV}$ impact energy with less than $1 \mathrm{~ns}$ pulse width was used. An electron gun was used to prevent charge buildup on the insulting sample surfaces. The total accumulated primary ion dose for data acquisition was less than $1 \times 10^{13}$ ions $/ \mathrm{cm}^{2}$, an amount of ions which is within the static SIMS regime. The mass resolution on $\mathrm{Si}$ wafer is about $\sim 8000 \mathrm{~m} / \Delta \mathrm{m}$ at 29AMU. For high lateral resolution mass spectral images acquired in this study, a Burst Alignment setting of $25 \mathrm{keV} \mathrm{Bi}_{3}{ }^{+}$ion beam was used to raster a $500 \mu \mathrm{m}$ by $500 \mu \mathrm{m}$ area. The negative secondary ion mass spectra obtained were calibrated using $\mathrm{C}^{-}, \mathrm{O}^{-}, \mathrm{OH}^{-}$, $\mathrm{C}_{\mathrm{n}}{ }^{-}$, respectively. The positive secondary ion mass spectra were calibrated using $\mathrm{H}^{+}, \mathrm{C}^{+}, \mathrm{C}_{2} \mathrm{H}_{3}{ }^{+}, \mathrm{C}_{3} \mathrm{H}_{5}{ }^{+}$, $\mathrm{C}_{4} \mathrm{H}_{7}{ }^{+}$.

\section{Results}

\section{Systematic Paleontology}

Order ASPIDORHYNCHIFORMES Bleeker, 1859

Family ASPIDORHYNCHIDAE Nicholson and Lydekker, 1889

Genus and Species Indet. (Fig. 2)

Referred material.-UR-CP-0001, caudal portion of a fish, missing the fins.

Locality and Age.-Radio Lenguerke station antenna region, Zapalonga locality (6 48'28.94' 'N, 73'16'08.23' 'W, 1703 m), southeast of Zapatoca, Santander Department, Colombia. The occurrence of the ammonoid Nicklesia pulchella (Fig. 1C) found in the same layer and concretions outcropping at this locality, indicates an early Barremian age for this locality following (Patarroyo 2009).

Remarks.-UR-CP-0001 is attributed to the Aspidorhynchidae family by the presence of rectangular high hypertrophied flank and nearly subquadrate covering the lateral and ventral sides of the trunk (Brito 1997; Cantalice et al. 2018) (Fig. 2G-J). Although further taxonomic resolution is not possible owing to 
159

160

161

162

163

164

165

166

167

168

169

170

171

172

173

174

175

176

177

178

179

180

181

182

183

184

185

186

187

188

189

190

191

192

193

194

195

196

197

198

its fragmentary preservation, the smooth surface of the flank scales resemble those of Vinctifer comptoni see (Cantalice et al. 2018), suggesting the possibility that this organism represents a member of this taxon. Aspidorhynchids constitute an extinct basal teleostean group from the Middle Jurassic to Late Cretaceous fishes that were highly specialized and lived in shallow epicontinental marine environments throughout America, Europe, Australia, Africa, Antarctica, and Middle East (Cantalice et al. 2018). The anterior portion the aspidorhynchid Vinctifer was previously reported from exposures of the Paja Formation cropping out near Villa de Leyva, in the Department of Boyacá (Schultze \& Stöhr 1996).

Description. UR-CP-0001 represents a caudal portion of a fish preserved three-dimensionally (Figs. 2A-D). The specimen is shaped like a truncated cone, which fits with the shape of caudal portions of others aspidorhynchids previously reported (Figure 2C). Also the orientation of the scales impressions left on the skin exhibit a pattern typical of the caudal region (Figure 2B).

It has a length of $128.5 \mathrm{~mm}$, an anterior height of $84 \mathrm{~mm}$, and a posterior height of $40 \mathrm{~mm}$. On the ventral surface there is a region that shows a scar that resembles the potential insertion of the anal fin. The edges of the specimen are completely eroded and no sign of bones are visible, which suggest that most of the anterior part of the specimen was probably lost prior the fossilization

Most of the laterals surfaces of the specimen bear a brown, wrinkled layer preserving 'skin' and covered in some places by rectangular black scales (Fig. 2B). These are, particularly visible on the right side (Fig. 2G), whereas on the ventral side there are small, square marks similar to the ventral scales (Fig. $2 \mathrm{H}, \mathrm{I})$. There are no vertebrae or spines visible on the naturally broken anterior or posterior surfaces (Fig. 2E, F) nor are any visible internally in Computed Tomography (CT) of the specimen, which is infilled by a heterogeneous black-gray and yellow carbonate matrix (hereinafter infilling matrix) that is high-porosity in some regions and reacts to $\mathrm{HCl}$ (Video $\mathrm{S} 1$ ).

After demineralization with either $\mathrm{HCl}$ or EDTA (Fig. 3A, B) isolated pieces of 'skin' from fragments of fossil material (handled following aseptic techniques (see methods) and no glues or preservatives were applied) were observed under transmitted light microscope, and were shown to be formed by two distinct layers. Similar layers were observed in the dry skin of the extant Orechromis sp. (Mojarra fish) (Fig. 3C) together to some parallel lines similar to fibers observed in the extant and the fossil (Fig. 3D, $\mathrm{F}, \mathrm{G})$. The most basal layer is a thin semitransparent film-like sheet; this layer is covered by a brown to black organic patchy layer, in some degraded regions form irregular reticular pattern (Fig 3I-K). The basal semitransparent layer is quite flexible when wet, but becomes rigid and fragile when dried (Video S2). Under polarized light, the basal layer of the HCl-treated samples exhibits small granules having a first order of birefringence, indicating a potential phosphatic composition. The external organic brown layer covering this basal layer remains of the same color when the polarizer is rotated (Fig. 3L-M). Pieces treated with EDTA showed higher degradation characterized by less and smaller fragments of both layers in contrast to those treated with $\mathrm{HCl}$ (Fig. S1). We consider the external organic brown layer is consistent with the most exterior morphological feature of the skin which is the epidermis (Elliott 
199

200

201

202

203

204

205

206

207

208

209

210

211

212

213

214

215

216

217

218

219

220

221

222

223

224

225

226

227

228

229

230

231

232

233

234

235

236

237

238

2011); also soft-tissue that are morphologically consistent with portions of the dermis were recovered after EDTA treatment, exhibiting collagen fibers (Fig. 3H).

SEM-EDS results. The untreated, uncoated skin is very smooth and uniform under SEM, which contrasts with the highly granular topography of the surrounding infilling matrix (Fig 4A-D). Point elemental analyses show predominant occurrence of carbon and nitrogen, with minor representation of calcium and phosphorus in the 'skin' layer (Fig. 4C). The infilling matrix contains predominantly calcium and carbon; no nitrogen was observed (Fig. 4D). Similar results were obtained using elemental mapping of the 'skin' and matrix (Fig 4G-L) however, nitrogen was not clearly observed.

FTIR results. FTIR spectrum of the untreated 'skin' sample showed distinct peaks at $2931 \mathrm{~cm}^{-1}, 1740$ $\mathrm{cm}^{-1}, 1591 \mathrm{~cm}^{-1}$ and around $1120 \mathrm{~cm}^{-1}$. EDTA-treated sample showed high infrared absorption peaks at 1703, 1540 and $3744 \mathrm{~cm}^{-1}$ respectively (Fig. 5A). The HCl-treated sample showed absorption peaks at 1724, 1142, and $1027 \mathrm{~cm}^{-1}$ (Fig. 5A). The commercial extant fish skin sample (Orechromis sp. mojarra fish), exhibited two well defined regions of peaks at 1746, 1647, 1559, and $1117 \mathrm{~cm}^{-1}$ and second one with peaks at 3319 and $2931 \mathrm{~cm}^{-1}$. In contrast, the infilling matrix from UR-CP-0001 showed clear peaks at $1428 \mathrm{~cm}^{-1}, 1030 \mathrm{~cm}^{-1} 876 \mathrm{~cm}^{-1}$ and $711 \mathrm{~cm}^{-1}$ (Fig. 5A).

ToF-SIMS results. ToF-SIMS analyses of both the untreated fossil 'skin' and the HCl-treated 'skin' show almost the same as each other negative and positive ions spectra (Fig. 6, Fig. S2); in particular, in abundance of $\mathrm{CN}^{-}$(Fig. 6C) and $\mathrm{CNO}^{-}$(Fig. 6F) negative ions; $\mathrm{CH}_{4} \mathrm{~N}^{+}$(Fig. 6D), $\mathrm{C}_{4} \mathrm{H}_{8} \mathrm{~N}^{+}$(Fig. 6E), $\mathrm{C}_{2} \mathrm{H}_{6} \mathrm{~N}^{+}$(Fig. 6G), and $\mathrm{C}_{3} \mathrm{H}_{6} \mathrm{~N}^{+}$(Fig. $6 \mathrm{H}$ ) positive ions were detected. All ions potentially derived from proteins are presented in Table 1, as well as all-raw data obtained from ToF-SIMS analyses can be found in the Data S1.

Integrated compositional characterization of the 'skin' and comparisons. As we showed using transmitted light, polarized light, and SEM-EDS microscopy (Figs. 3, 4); the preservation of the 'skin' in UR-CP-0001 resulted from an organic and inorganic interaction forming two well defined layers (Fig. $3 \mathrm{~J}, \mathrm{~K}$ ) each of them exhibiting distinct physical and chemical characteristics. The basal layer is translucent, granular to film-like in appearance. This layer is interpreted as inorganic in composition, potentially phosphates, based on its birefringence pattern (Fig. 3M), the abundance of phosphorus showed by the EDS analysis (Fig. 4G, K-Phosphorus) together with the high absorbance peaks at 1177 and $998 \mathrm{~cm}^{-1}$ observed in the FTIR spectra. These peaks are particularly intense in the UR-CP-0001 sample (Fig. 5A), and were reported in an FTIR analysis of Vinctifer comptoni from the Cretaceous of Brazil (Sousa Filho et al. 2016). Similar peaks at this region have been interpreted as four infrared absorption bands of phosphate $\left(\mathrm{vPO}_{4}{ }^{3-} 1120 \mathrm{~cm}^{-1}, \mathrm{v}_{3 \mathrm{a}} \mathrm{PO}_{4}{ }^{3-} 1112 \mathrm{~cm}^{-1}, \mathrm{v}_{3 \mathrm{c}} \mathrm{PO}_{4}{ }^{3-} 1007 \mathrm{~cm}^{-1}\right.$ and $\mathrm{v}_{1} \mathrm{PO}_{4}$ ${ }^{3-} 966 \mathrm{~cm}^{-1}$ ) (Lee et al. 2017). Occurrence of phosphates and carbonates could be inferred from both SEM-EDS and FTIR analyses (Figs. 4K, L; 5A) in the infilling matrix similar to the typical calcium carbonate FTIR spectrum (Bosch-Reig et al. 2002). The more external layer of the 'skin' in UR-CP0001 is brown to black, and is consistent with organic material when analyzed under polarized light 
239 (Fig. 3M). Its organic composition supported by the SEM-EDS point and map analyses, which showed 240 particularly high levels of carbon and nitrogen (Fig. 4C, H). Another remarkable finding that supports 241 the organic composition of this layer is its morphological change after being exposed to $10 \mathrm{kV}$ for 242 mapping EDS analysis becoming highly corrugated (Fig. 4E,F), which typically happens to uncoated 243 organic tissue or structures under high voltage in SEM similar as degradation of non-conductive 244 materials (Kersten 2009).

245

246

247

248

249

250

251

252

253

254

255

256

257

258

259

260

261

262

263

264

265

266

267

268

269

270

271

272

273

274

275

276

277

278

FTIR analysis confirmed that the carbon rich layer we found with the EDS is composed by organic residues particularly the $\mathrm{C}-\mathrm{H}$ stretch and $\mathrm{v}(\mathrm{C}=\mathrm{O})$ peaks around 2931 and 1737 respectively (Fig. 5A), which are commonly found in collagen I (Belbachir et al. 2009; Jeevithan et al. 2014; Valenzuela-Rojo et al. 2018) and keratin (Chandini et al. 2017; Estévez-Martínez et al. 2013); highly abundant proteins found in the scales and skin of fishes (Bhagwat \& Dandge 2016; Elliott 2011). Amide A, I, II, and III, $\mathrm{C}-\mathrm{H}$ stretch and $\mathrm{v}(\mathrm{C}=\mathrm{O})$ peaks were clearly observed in the FTIR of the extant Orechromis sp. (mojarra fish) skin used as standard for comparison (Fig. 5A). Peaks potentially corresponding to Amide I and II were also found in the deconvoluted spectrum of the 'skin' untreated sample (Fig. 5D), falling inside the range of vibrational bands as product of possible diagenetic alterations of the original organic compounds, similar as occurs in FTRI analyses of modern proteins (Kong \& Yu, 2007). We exclude a potential bacterial origin of the organic component of the 'skin' in UR-CP-0001 because FTIR spectra lack of the characteristic broad infrared absorption band of hydroxyl group (-OH) of polysaccharides at 3700-3100 $\mathrm{cm}^{-1}$ (Lee et al. 2017; Lindgren et al. 2011). ToF-SIMS results of the two samples of URCP-0001 analyzed also show the occurrence of molecular organic fragments, including the positive $\mathrm{CH}_{4} \mathrm{~N}^{+}$(Fig. 6D), $\mathrm{C}_{4} \mathrm{H}_{8} \mathrm{~N}^{+}$(Fig. 6E), $\mathrm{C}_{2} \mathrm{H}_{6} \mathrm{~N}^{+}$(Fig. 6G), $\mathrm{C}_{3} \mathrm{H}_{6} \mathrm{~N}^{+}$(Fig. 6H) and $\mathrm{C}_{7} \mathrm{H}_{7} \mathrm{O}^{+}$which are typical residues of glycine, alanine, proline and tyrosine constituents of collagen and fibronectin (Brüning et al. 2006; Henss et al. 2013). Two other ions that support potential organic preservation in the 'skin' of URCP-0001 are $\mathrm{CN}^{-}$(Fig. 6C) and $\mathrm{CNO}^{-}$(Fig. 6F) negative ions particularly abundant in melanosomes and melanin (Lindgren et al. 2018; Lindgren et al. 2012), and although we can not reject at this point that they could be from another source, our hypothesis seems to be plausible. A complete tentative assignment of ions derived from proteins based on $\mathrm{m} / \mathrm{z}$ values in UR-CP-0001 samples and theoretical mass is presented in Table 1. We exclude a potential mineralized biofilm source of protein residues based on the FITR spectra (Fig. 5A) and the absence of any morphological features associated to bacteria origin (filaments or spheres) (Kaye et al. 2008; Schweitzer et al. 2016).

The preservation of the 'skin' in UR-CP-001 is also supported by its morphological corrugated macroscopic appearance (Fig. 2G, 3E) resembling a phenomenon that occurs to the skin from extant fishes where in absence of scales that leaves the skin without an external support structure, make it more susceptible to wrinkling under a compression stress (Vernerey \& Barthelat 2014), due to dehydration or in a post mortem deformation (Lindgren et al. 2018) (Fig. 3C, E). Additionally, collagen fibers were observed in both UR-CP-0001 'skin' and the dehydrated skin from extant Orechromis sp. (mojarra fish) also to microscopic level after EDTA demineralization of 'skin' (Fig. 3D, G, H) supporting the interpretation of UR-CP-0001 as an exceptional preserved fossilized skin.

Peer) reviewing PDF | (2020:03:46405:2:0:NEW 9 Jun 2020) 


\section{Discussion}

281

282

283

Aspidorhynchid fishes had widespread geographic and temporal distribution with fossils reported in all continents from the Middle Jurassic to Late Cretaceous (BRITO 1997). Specimen UR-CP-0001

284

285 represents the earliest known record for an aspidorynchid in Colombia, extending the temporal range from Aptian (Schultze \& Stöhr 1996) to Barremian. Once again, a peri-Gondwanan distribution of Vinctifer (Fig. S3) is confirmed here, as UR-CP-0001 potentially belongs to this genus (see Remarks).

287

288

Vibrational spectroscopic techniques such FTIR demonstrates its reliability to understand fossil preservation mechanisms, due to its sensitiveness to organic functional groups and phosphates thought high peak bands (Diaz et al. 2020; Olcott Marshall \& Marshall 2015). However due the noise signals a

291

292

293

294

295

296

297

298

299

300

301

302

303

304

305

306

307

308

309

310

311

312

313

314

315

316

317

318 deconvolution was needed to unveil masked absorbance peaks from the raw data. ToF-SIMS also give more resolution to identify the nature of preserved components. These kind of analysis has demonstrate to be trustful for inferences about preservation mechanisms and track the origin of the preserved molecules (Bezerra et al. 2020; Diaz et al. 2020).

Although it is hard to reconstruct the complete chain of taphonomical events that occurred to UR-CP0001, we hypothesize that besides fragmentation and fins disarticulation without losing the conical shape of its caudal region, the nature of its scales and skin played a key role in its preservation. The presence of scales and the thickness of the fossilized 'skin' suggest a possible mechanism of preservation that we call a "microsandwich effect", which could apply to many other fragmentary fossil fishes that have not been studied for molecular paleontology. Scales may have acted as an external barrier against bacteria and other environmental decay accelerators, which could decompose the integument. Simultaneously, the basal layer became enriched in phosphate, possibly resulting from the degradation of phosphate containing organic compounds from the dermis itself, as has been reported in other fossilized skin from vertebrates (McNamara et al. 2009), at the same time this layer may have acted as an internal barrier, creating an encapsulating environment for the integument. These local biogeochemical interactions would favor not only preservation of the general morphology of the skin, but also some of their soft-tissue structures and residues of the original biomolecules by geopolymerization (Lindgren et al. 2018). Another factor that potentially played a key role in the preservation of the 'skin' in UR-CP-0001 was the burial environment conditions, dominated by organicrich shale interval showing characteristics of oxygen depleted conditions at the lower segment of Paja Formation in this region (Gaona-Narvaez et al. 2013). Microcrystalline minerals like clays and shales have extremely large surface area to volume ratios, and are usually charged, both of which favor adsorption and inactivation of degrading enzymes, similar been proposed for the exceptional preservation of Burgess Shale fossils (Butterfield 1990).

Our results imply that the Paja Formation could be potentially considered as the third locality in South America were exceptional preservation in fishes have been reported, alongside with the Brazilian 
319 Romualdo and Crato Formations, where the preservation mechanisms is well known (Osés et al. 2017).

320 The mechanism of preservation proposed here, as well as other recent work (Lindgren et al. 2018)

321 increases the number of potential scenarios for preservation of cellular-to-subcellular soft tissue

322 morphology in fossils additional to oxidative depositional environments (Wiemann et al. 2018), where

323 iron play a key role (Schweitzer et al. 2014). As we showed in here, iron was not detected in UR-CP-

324 0001, suggesting that in molecular paleontology studies there will be always exceptions to those

325 formulated general trends and factors favoring preservation in deep time, and that each case and fossil

326 site needs to be considered with its own particularities.

327

328

329

330

331

332

333

334

335

336

337

338

339

340

341

342

343

344

345

346

347

348

349

350

351

352

353

354

355

356

357

358

359

\section{Conclusions}

Exceptional preserved 'skin' from an aspidorhynchid fish represents the first report of soft tissue preservation in vertebrates from the Early Cretaceous in north South America. Morphological

comparisons and molecular analyses present several similar features between the extant fish skin and the fossilized specimen. Molecular analyses also provide evidence of possible proteinaceous residues preserved in the fossilized skin which is supported by vibrational peaks associated with Amide I and II in the FTIR spectra and signals that can be associated to aminoacids like Glycine and Lysine. Because of the limitation in the project funding, future analyses should be focused on immunohistochemistry, testing specific fish skin antibodies and other mass spectrometry techniques including LC-MS/MS to confirm the preservation of original proteinaceous components.

\section{Acknowledgements}

We thank to E. Realpe for allowing us to use the stereomicroscope. Special thanks to A. Link for helping us with the logistics and permits necessary to use the Universidad de los Andes facilities. Thanks to M. Negrete and the radiology team at the Hospital Méderi for access to the CT-scan. Thanks to M. López and H. Pinto from the Universidad de los Andes, Bogotá for the scanning this fossil with the SEM-EDS and the analyses performed with the FTIR spectrometer. Thanks to Y. Rojas for allow us the use of the polarized transmitted light microscope at Universidad de los Andes. Thanks to A. Forero and L. Daza for assistance during lab preparation of the samples. Thanks to C. Zhou for the ToF-SIMS analyses. Special thanks to M. Schweitzer and J. A. Wilson, as well as to M. Benton and an anonymous reviewer for valuable comments on the manuscript. Funding for this project was granted to E-A. C from Universidad del Rosario, Capital Semilla grants program 2019 and Fondos de Arranque 2018.

\section{References}

Bailleul AM, Zheng W, Horner JR, Hall BK, Holliday CM, Schweitzer MH. 2020. Evidence of proteins, chromosomes and chemical markers of DNA in exceptionally preserved dinosaur cartilage. National Science Review 0:1-8.

Belbachir K, Noreen R, Gouspillou G, Petibois C. 2009. Collagen types analysis and differentiation 
360

361

362

363

364

365

366

367

368

369

370

371

372

373

374

375

376

377

378

379

380

381

382

383

384

385

386

387

388

389

390

391

392

393

394

395

396

by FTIR spectroscopy. Analytical and bioanalytical chemistry 395:829-837.

Bezerra FI, da Silva JH, de Castro Miguel E, Paschoal AR, Nascimento DR, Freire PT, Viana BC, and Mendes M. 2020. Chemical and mineral comparison of fossil insect cuticles from Crato Konservat Lagerstätte, Lower Cretaceous of Brazil. Journal of Iberian Geology:1-16.

Bhagwat PK, Dandge PB. 2016. Isolation, characterization and valorizable applications of fish scale collagen in food and agriculture industries. Biocatalysis and agricultural biotechnology 7:234-240.

Boatman E, Goodwin MB, Holman HYN, Fakra SC, Zheng W, Gronsky R, Schweitzer MH. 2019. Mechanisms of soft tissue and protein preservation in Tyrannosaurus rex. Scientific Reports 9:15678.

Bosch-Reig FB, Gimeno-Adelantado JVG, Moya-Moreno MCM. 2002. FTIR quantitative analysis of calcium carbonate (calcite) and silica (quartz) mixtures using the constant ratio method. Applications to geological samples. Talanta 58:811-821.

Brito PM. 1997. Révision des Aspidorhynchidae (Pisces, Actinopterygii) du Mésozoïque: ostéologie, relations phylogénétiques, données environnementales et biogéographiques. Geodiversitas 19:681-772.

\section{Brown CM, Henderson DM, Vinther J, Fletcher I, Sistiaga A, Herrera J, Summons RE. 2017. An} exceptionally preserved three-dimensional armored dinosaur reveals insights into coloration and Cretaceous predator-prey dynamics. Current Biology 27:2514-2521. e2513.

Brüning C, Hellweg S, Dambach S, Lipinsky D, Arlinghaus HF. 2006. Improving the interpretation of ToF-SIMS measurements on adsorbed proteins using PCA. Surface and Interface Analysis 38:191193.

Butterfield NJ. 1990. Organic preservation of non-mineralizing organisms and the taphonomy of the Burgess Shale. Paleobiology 16:272-286.

Cadena E. 2016. Microscopical and elemental FESEM and Phenom ProX-SEM-EDS analysis of osteocyte-and blood vessel-like microstructures obtained from fossil vertebrates of the Eocene Messel Pit, Germany. PeerJ 4:e1618.

Cadena EA. 2015. The first South American sandownid turtle from the Lower Cretaceous of Colombia. PeerJ 3:e1431.

Cadena EA, Parham JF. 2015. Oldest known marine turtle? A new protostegid from the Lower Cretaceous of Colombia. PaleoBios 32:1-45. 
400

401

402

403

404

405

406

407

408

409

410

411

412

413

414

415

416

417

418

419

420

421

422

423

424

425

426

427

428

429

430

431

432

433

434

435

436

Cadena EA, Parra-Ruge ML, Parra-Ruge JdD, Padilla-Bernal S. 2019. A gravid fossil turtle from the Early Cretaceous reveals a different egg development strategy to that of extant marine turtles. Palaeontology 62:533-545.

Cadena EA, Schweitzer MH. 2012. Variation in osteocytes morphology vs. bone type in turtle shell and their exceptional preservation from the Jurassic to the present. Bone 51:614-620.

Caldwell MW, Sasso CD. 2004. Soft-tissue preservation in a 95 million year old marine lizard: form, function, and aquatic adaptation. Journal of Vertebrate Paleontology 24:980-985.

Cantalice KM, Alvarado-Ortega J, Brito PM. 2018. Sobre la ocurrencia de Vinctifer ferrusquiai sp. nov. (Actinopterygii, Aspidorhynchiformes) en los depósitos Kimmeridgianos (Jurásico Tardío) cercanos a Tlaxiaco, Oaxaca, sur de México. Revista Mexicana de Ciencias Geológicas 35:179-187.

\section{Carballido JL, Pol D, Parra-Ruge ML, Padilla-Bernal S, Páramo-Fonseca ME, Etayo-Serna F.}

2015. A new Early Cretaceous brachiosaurid (Dinosauria, Neosauropoda) from northwestern Gondwana (Villa de Leiva, Colombia). Journal of Vertebrate Paleontology 35:1-12.

Chandini DS, Charulatha M, Legadevi R, Meignanalakshmi S. 2017. In Vitro Evaluation of Natural Keratin Based Hydrogel from Chicken Feather Waste for Controlled Drug Release. International Journal of Current Microbiology Applied Science 6:3488-3495.

Chernova O. 2009. Skin derivatives in vertebrate ontogeny and phylogeny. Biology Bulletin 36:175183.

Diaz MAL, D'Angelo JA, Del Fueyo GM, and Carrizo MA. 2020. FTIR spectroscopic features of the pteridosperm Ruflorinia orlandoi and host rock (Springhill Formation, Lower Cretaceous, Argentina). Journal of South American Earth Sciences 99:102520.

\section{Cleland TP, Schroeter ER, Zamdborg L, Zheng W, Lee JE, Tran JC, Bern M, Duncan MB,}

Lebleu VS, Ahlf DR. 2015. Mass spectrometry and antibody-based characterization of blood vessels from Brachylophosaurus canadensis. Journal of Proteome Research 14:5252-5262.

Coria RA, Chiappe LM. 2007. Embryonic skin from Late Cretaceous sauropods (Dinosauria) of Auca Mahuevo, Patagonia, Argentina. Journal of Paleontology 81:1528-1532.

Elliott D. 2011. Functional Morphology of the Integumentary System in Fishes. In: Farrell A.P., (ed.), Encyclopedia of Fish Physiology: From Genome to Environment, volume 1, pp. 476-488. San Diego: Academic Press. 
437 Estévez-Martínez Y, Velasco-Santos C, Martínez-Hernández A-L, Delgado G, Cuevas-Yáñez E, 438 Alaníz-Lumbreras D, Duron-Torres S, Castaño VM. 2013. Grafting of multiwalled carbon nanotubes

439

440

441

442

443

444

445

446

447

448

449

450

451

452

453

454

455

456

457

458

459

460

461

462

463

464

465

466

467

468

469

470

471

472

473

474

475 with chicken feather keratin. Journal of Nanomaterials 2013:702157.

Gaona-Narvaez T, Florentin J-MM, Etayo-Serna F. 2013. Geochemistry, palaeoenvironments and timing of Aptian organic-rich beds of the Paja Formation (Curití, Eastern Cordillera, Colombia). Geological Society, London, Special Publications 382:31-48.

Grellet-Tinner G, Codrea V, Folie A, Higa A, Smith T. 2012. First evidence of reproductive adaptation to "Island effect" of a dwarf Cretaceous Romanian titanosaur, with embryonic integument in ovo. PLoS One 7:e32051.

Hall JP, Wolberg DL, West S. 1988. Dinosaur-skin impressions from the Fruitland Formation (Campanian-Maastrichtian) of the Fossil Forest, San Juan Basin, San Juan County, New Mexico. New Mexico Bureau of Mines and Mineral Resources Bulletin 122:23-27.

Henss A, Rohnke M, El Khassawna T, Govindarajan P, Schlewitz G, Heiss C, Janek J. 2013. Applicability of ToF-SIMS for monitoring compositional changes in bone in a long-term animal model. Journal of The Royal Society Interface 10:20130332.

Jeevithan E, Bao B, Bu Y, Zhou Y, Zhao Q, Wu W. 2014. Type II collagen and gelatin from silvertip shark (Carcharhinus albimarginatus) cartilage: Isolation, purification, physicochemical and antioxidant properties. Marine drugs 12:3852-3873.

Kaye TG, Gaugler G, Sawlowicz Z. 2008. Dinosaurian soft tissues interpreted as bacterial biofilms. PLoS One 3:e2808.

Kellner AW, Campos DA, Sayao JM, Saraiva AA, Rodrigues T, Oliveira G, Cruz LA, Costa FR, Silva HP, and Ferreira JS. 2013. The largest flying reptile from Gondwana: a new specimen of Tropeognathus cf. T. mesembrinusWellnhofer, 1987 (Pterodactyloidea, Anhangueridae) and other large pterosaurs from the Romualdo Formation, Lower Cretaceous, Brazil. Anais da Academia Brasileira de Ciências 85:113-135.

Kersten K. 2009. Sample degradation during SEM analysis: what causes it and how to slow down the process. https://blog.phenom -world.com/. Accessed: February 2020.

Kong J, Yu S. 2007. Fourier Transform Infrarred Spectroscopic Analysis of Protein Secondary Structures. Acta Biochimica et Biophysica Sinica 39:549-559. 
476 Lee Y-C, Chiang C-C, Huang P-Y, Chung C-Y, Huang TD, Wang C-C, Chen C-I, Chang R-S, 477 Liao C-H, Reisz RR. 2017. Evidence of preserved collagen in an Early Jurassic sauropodomorph 478 dinosaur revealed by synchrotron FTIR microspectroscopy. Nature Communications 8:14220.

479

480

481

482

483

484

485

486

487

488

489

490

491

492

493

494

495

496

497

498

499

500

501

502

503

504

505

506

507

508

509

510

511

512

513

514 Martin T, Marugán-Lobón J, Vullo R, Martín-Abad H, Luo Z-X, Buscalioni AD. 2015. A

515

Lindgren J, Everhart MJ, Caldwell MW. 2011a. Three-dimensionally preserved integument reveals hydrodynamic adaptations in the extinct marine lizard Ectenosaurus (Reptilia, Mosasauridae). PLoS One 6:e27343.

\section{Lindgren J, Uvdal P, Engdahl A, Lee AH, Alwmark C, Bergquist KE, Nilsson E, Ekström P,} Rasmussen M, Douglas DA, Polcyn MJ, Jacobs LL. 2011b. Microspectroscopic evidence of Cretaceous bone proteins. PLoS One 6:e19445.

Lindgren J, Kaddumi HF, Polcyn MJ. 2013. Soft tissue preservation in a fossil marine lizard with a bilobed tail fin. Nature Communications 4:2423.

\section{Lindgren J, Sjövall P, Thiel V, Zheng W, Ito S, Wakamatsu K, Hauff R, Kear BP, Engdahl A,} Alwmark C. 2018. Soft-tissue evidence for homeothermy and crypsis in a Jurassic ichthyosaur. Nature 564:359-365.

Lindgren J, Uvdal P, Sjövall P, Nilsson E, Engdahl A, Schultz BP, and Thiel V. 2012. Molecular preservation of the pigment melanin in fossil melanosomes. Nature Communications 3:824.

Lingham-Soliar T, Plodowski G. 2010. The integument of Psittacosaurus from Liaoning Province, China: taphonomy, epidermal patterns and color of a ceratopsian dinosaur. Naturwissenschaften 97:479486.

Maisey JG. 1991. Santana fossils: an illustrated atlas: TFH Publications Incorporated, Neptune, pp. 462.

Manning PL, Morris PM, McMahon A, Jones E, Gize A, Macquaker JH, Wolff G, Thompson A, Marshall J, Taylor KG. 2009. Mineralized soft-tissue structure and chemistry in a mummified hadrosaur from the Hell Creek Formation, North Dakota (USA). Proceedings of the Royal Society B: Biological Sciences 276:3429-3437.

Martill DM. 1988. Preservation of fish in the Cretaceous Santana Formation Brazil. Palaeontology, 31:1-18.

Martill DM. 1989. The Medusa effect: instantaneous fossilization. Geology Today 5:201-205.

Cretaceous eutriconodont and integument evolution in early mammals. Nature 526:380-384.

Peer) reviewing PDF | (2020:03:46405:2:0:NEW 9 Jun 2020) 
517 Maxwell EE, Cortés D, Patarroyo P, Ruge MLP. 2019. A new specimen of Platypterygius

518 sachicarum (Reptilia, Ichthyosauria) from the Early Cretaceous of Colombia and its phylogenetic

519 implications. Journal of Vertebrate Paleontology 39: e1577875.

520

521

McNamara ME, Zhang F, Kearns SL, Orr PJ, Toulouse A, Foley T, Hone DW, Rogers CS, Benton

522 MJ, Johnson D. 2018a. Fossilized skin reveals coevolution with feathers and metabolism in feathered

523 dinosaurs and early birds. Nature Communications 9:2072.

524

525

McNamara ME, Kaye JS, Benton MJ, Orr PJ, Rossi V, Ito S, Wakamatsu K. 2018b. Non-

526 integumentary melanosomes can bias reconstructions of the colours of fossil vertebrates. Nature

527 Communications 9:2878.

528

529

McNamara ME, Orr PJ, Kearns SL, Alcalá L, Anadón P, Peñalver E. 2016. Reconstructing

530 carotenoid-based and structural coloration in fossil skin. Current Biology 26:1075-1082.

531

532

McNamara ME, Orr PJ, Kearns SL, Alcalá L, Anadón P, Peñalver-Mollá E. 2009. Soft-tissue

533 preservation in Miocene frogs from Libros, Spain: insights into the genesis of decay microenvironments.

534 Palaios 24:104-117.

535

536

Micklich N. 2002. The fish fauna of Messel Pit: A nursery school?. Courier-Forschungsinstitut

537

Senckenberg 237:97-127.

538

539

Olcott Marshall A, and Marshall CP. 2015. Vibrational spectroscopy of fossils. Palaeontology

540 58:201-211.

541

542

Osés GL, Petri S, Voltani CG, Prado GM, Galante D, Rizzutto MA, Rudnitzki ID, da Silva EP,

543 Rodrigues F, and Rangel EC. 2017. Deciphering pyritization-kerogenization gradient for fish soft-

544 tissue preservation. Scientific reports 7:1-15.

545

546

Paik IS, Kim HJ, Huh M. 2010. Impressions of dinosaur skin from the Cretaceous Haman Formation

547 in Korea. Journal of Asian Earth Sciences 39:270-274.

548

549

Páramo-Fonseca ME, Gómez-Pérez M, Noé LF, Etayo-Serna F. 2016. Stenorhynchosaurus munozi,

550 gen. et sp. nov. a new pliosaurid from the Upper Barremian (Lower Cretaceous) of Villa de Leiva, Colombia, South America. Revista de la Academía Colombiana de Ciencias Exactas, Físicas, y

552 Naturales 40:84-103.

553

554

Patarroyo P. 2009. Amonitas de un nivel de alta energía del Barremiano inferior en la Formación Paja 555 de los sectores de Villa de Leyva (Boyacá) y de Vélez (Santander). Boletín de Geología 31:15-21. 
556

557

558

559

560

561

562

563

564

565

566

567

568

569

570

571

572

573

574

575

576

577

578

579

580

581

582

583

584

585

586

587

588

589

590

591

592

593

Samuel NT, Wagner MS, Dornfeld KD, Castern DG. 2001. Analysis of Poly (amino acids) by Static Time-of-Flight Secondary Ion Mass Spectrometry (TOF-SIMS). Surface Science Spectra 8:163-184.

Schultze H-P, Stöhr D. 1996. Vinctifer (Pisces, Aspidorhynchidae) aus der unterkreide (oberes Aptium) von Kolumbien. Neues Jahrbuch für Geologie und Paläontologie-Abhandlungen 199:395-415.

Schweitzer MH. 2011. Soft tissue preservation in terrestrial Mesozoic vertebrates. Annual Review of Earth and Planetary Sciences 39:187-216.

Schweitzer MH, Moyer AE, Zheng W. 2016. Testing the hypothesis of biofilm as a source for soft tissue and cell-like structures preserved in dinosaur bone. PLoS One 11:e0150238.

\section{Schweitzer MH, Zheng W, Cleland TP, Goodwin MB, Boatman E, Theil E, Marcus MA, Fakra} SC. 2014. A role for iron and oxygen chemistry in preserving soft tissues, cells and molecules from deep time. Proceedings of the Royal Society B: Biological Sciences 281:20132741.

Signore M, Bucci E, Pede C, Barbera C. 2005. A new ichthyodectid fish from the Lower Cretaceous of Pietraroja (Southern Italy). PalArch 5:25-29.

Sionkowska A, Kozlowska J. 2014. Fish scales as a biocomposite of collagen and calcium salts. Key Engineering Materials 587:185-190.

\section{Sousa Filho F, da Silva J, Saraiva G, Abagaro B, Barros O, Saraiva A, Viana B, Freire P. 2016.} Spectroscopic studies of the fish fossils (Cladocyclus gardneri and Vinctifer comptoni) from the Ipubi Formation of the Cretaceous Period. Spectrochimica Acta Part A: Molecular and Biomolecular Spectroscopy 157:124-128.

Valenzuela-Rojo DR, López-Cervantes J, and Sánchez-Machado DI. 2018. Tilapia (Oreochromis aureus) Collagen for Medical Biomaterials. Seaweed Biomaterials. doi.org/10.5772/intechopen.77051.

Varejão FG, Warren LV, Simões MG, Fürsich FT, Matos SA, and Assine ML. 2019. Exceptional preservation of soft tissues by microbial entombment: insights into the taphonomy of the Crato Konservat-Lagerstätte. Palaios 34:331-348.

Vernerey FJ, Barthelat F. 2014. Skin and scales of teleost fish: Simple structure but high performance and multiple functions. Journal of the Mechanics and Physics of Solids 68:66-76. 
594 Vernygora O, Murray AM, Luque J, Ruge MLP, Fonseca MEP. 2018. A new Cretaceous dercetid 595 fish (Neoteleostei: Aulopiformes) from the Turonian of Colombia. Journal of Systematic Palaeontology 596 16:1057-1071.

597

598 Wiemann J, Fabbri M, Yang T-R, Stein K, Sander PM, Norell MA, Briggs DE. 2018. Fossilization 599 transforms vertebrate hard tissue proteins into N-heterocyclic polymers. Nature Communications 600 9:4741.

601

602 Xu X, Zhou Z, Wang Y, and Wang M. 2020. Study on the Jehol Biota: Recent advances and future 603 prospects. Science China Earth Sciences:1-17

604 


\section{Figure 1}

Locality and other reported exceptionally preserved skin fossils from the Cretaceous

Figure 1. Locality and others reported exceptionally preserved skin fossils from the Cretaceous. (A) map of Colombia showing in orange the Santander department, and the fish fossil site (Zapalonga locality) very near Zapatoca. (B) outcrop view at the fish fossil site, showing the presence of mudstones and large concretions. (C) stratigraphic column along with Zapalonga locality, indicating the horizon where UR-CP-0001 was found. (D) world map with remarkable findings of exceptional preserved skin fossils through the Cretaceous: (1) Barremian, Paja Fm, Colombia (this study); (2) Barremian, Calizas de la Huérgina Fm, Spain (Martin et al. 2015); (3) Barremian-Aptian, Huajiying and Yixian formations (Xu et al. 2020) Yixian Fm, China (Lingham-Soliar \& Plodowski 2010); (4) Aptian, Clearwater Fm, Canada (Brown et al. 2017); (5) Aptian-Albian, Romulado Fm, Brazil (Martill 1988); (6) Aptian-Albian, Haman Fm, South Korea (Paik et al. 2010); (7) Albian, Pietraroja, Italy (Signore et al. 2005); (8) Cenomanian, Hadjula, Lebanon (Caldwell \& Sasso 2004); (9) Cenomanian, Nobrara Fm, Kansas, United States (Lindgren et al. 2011a); (10) Campanian, Auca Mahuevo, Argentina (Coria \& Chiappe 2007); (11) Campanian-Maastrichtian, Fruitland Fm, New Mexico, United States (Hall et al. 1988); (12) Maastrichtian, Hell Creek Fm, North Dakota, United States (Manning et al. 2009); (13) Maastrichtian Harrana, Jordan (Lindgren et al. 2013); (14) Maastrichtian, Sânpetru Fm, Romania (Grellet-Tinner et al. 2012). 


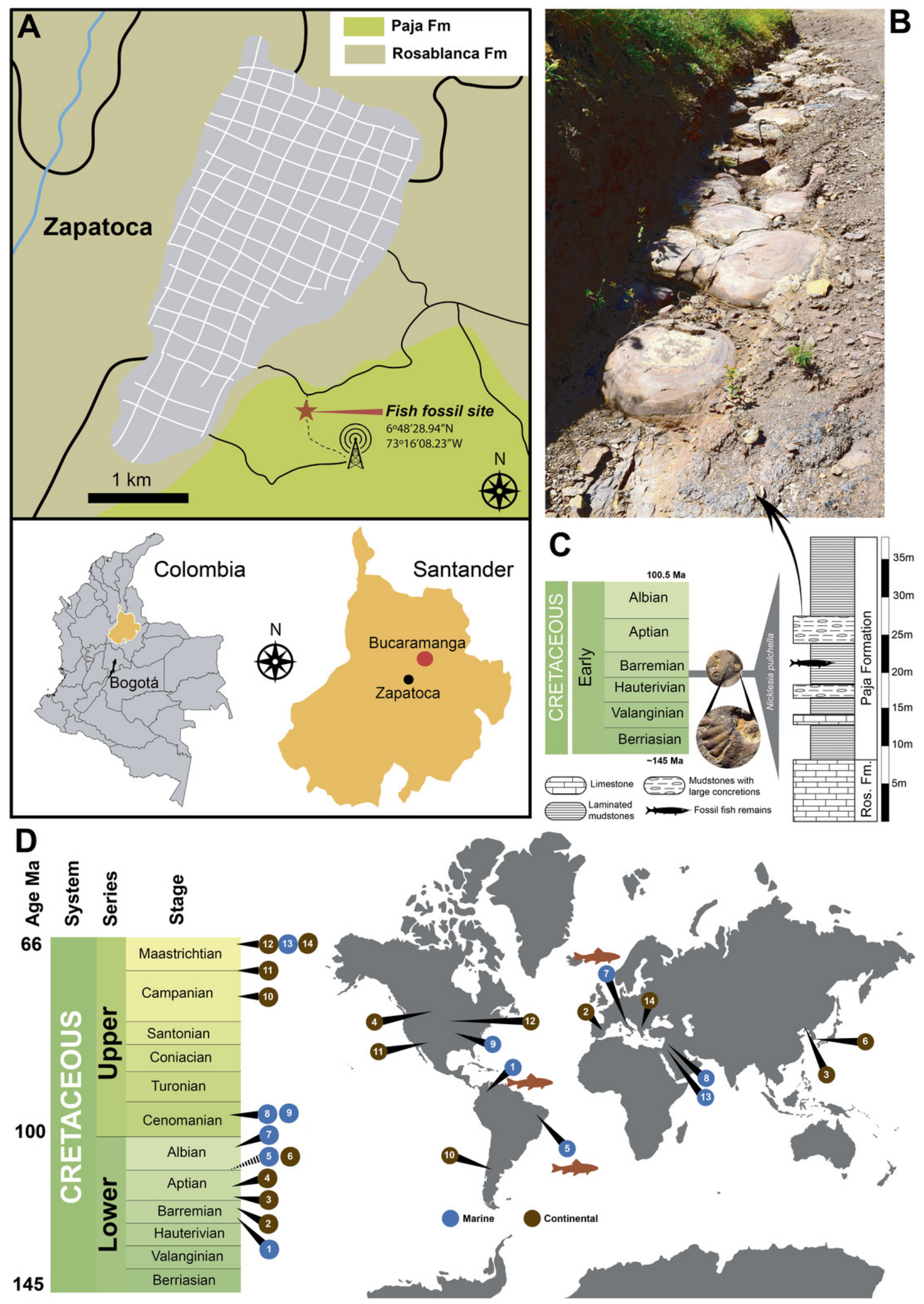




\section{Figure 2}

UR-CP-0001, aspidorhynchid fossil fish specimen

Figure 2. UR-CP-0001, aspidorhynchid fossil fish specimen. (A-B) right lateral view. (C) interpreted position of UR-CP-0001 in the body of an aspidorhynchid fish. (D) left lateral view. (E) ventral view. (F) posterior view, showing the naturally preserved original 3-D volume. (G) detail of the originally preserved 'skin' with wrinkles and marks. (H) View of some of the ventral scales (vs) preserved. (I-J) elongated ventral flank scales (vfs). $5 \mathrm{~cm}$ scale applies for $A, D, E$ and $F ; 2 \mathrm{~cm}$ for $\mathrm{G} ; 1.5 \mathrm{~cm}$ for $\mathrm{H}$ and $1 \mathrm{~cm}$ for $\mathrm{I}$ and $\mathrm{J}$. 

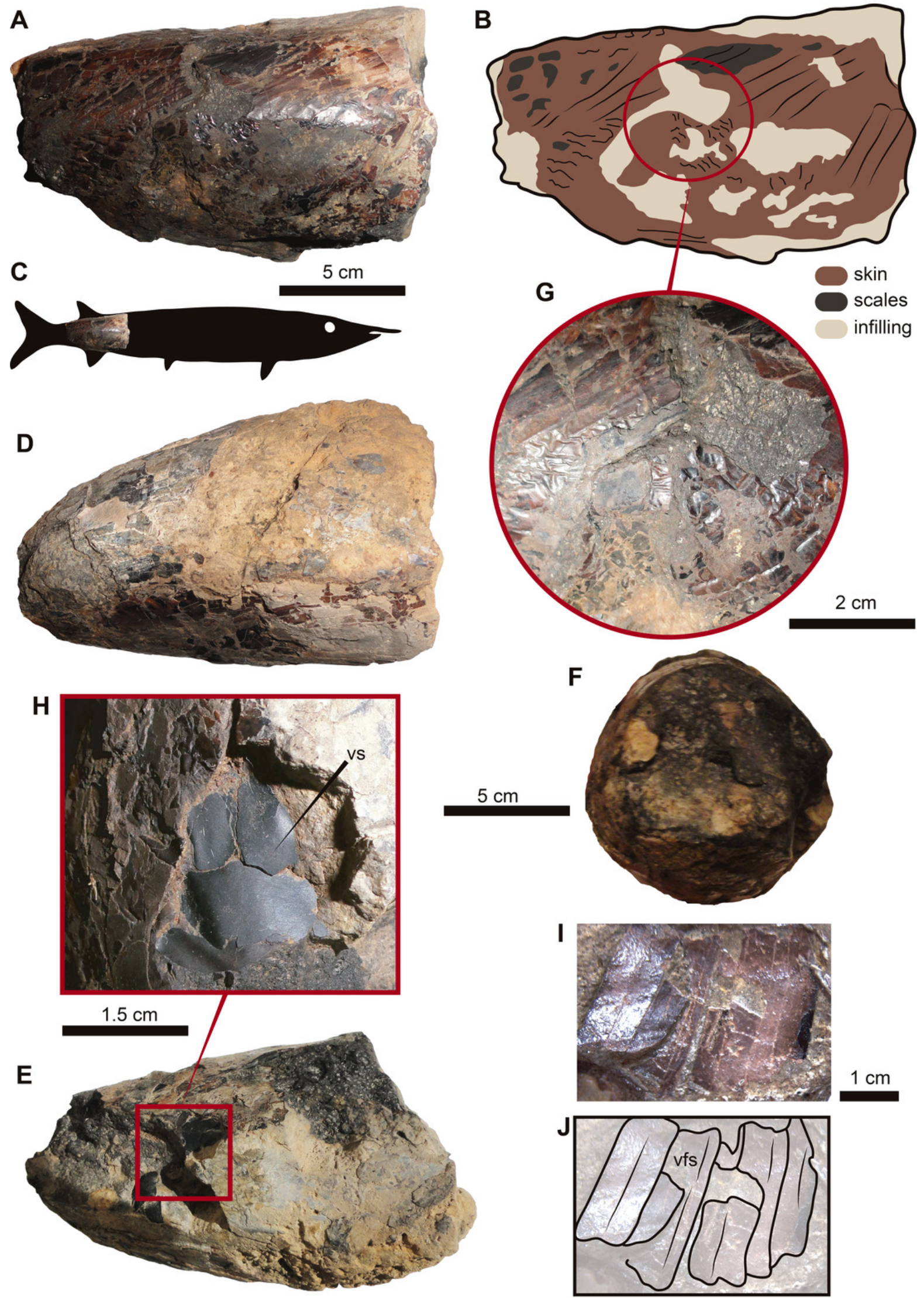


\section{Figure 3}

Some 'skin' fragments after $\mathrm{HCl}$ treatment

Figure 3. Some 'skin' fragments after $\mathrm{HCl}$ treatment. (A) light micrograph of preserved 'skin' after treated with $15 \% \mathrm{HCl}$, without any infilling matrix left. (B) enlargement of the organic patchy layer. (C-D) fragment of the dry skin of the extant Orechromis sp. (Mojarra fish) exhibiting two layers, wrinkles and collagen fibers indicated by black arrows in $\mathrm{d}$. (E) wrinkled 'skin' of UR-CP-0001. (F-G) an UR-CP-0001 close-up of the two organic exterior layers and collagen fibers indicated by black arrows in $\mathbf{g .}(\mathbf{H})$ isolated tissue fragment after EDTA treatment under transmitted-light microscopy showing collagen fibers. (I-K) an URCP-0001 'skin' fragment under transmitted-light microscope, exhibiting the two distinct inorganic (base) and organic (exterior) layers. (L-M) an UR-CP-0001 'skin' fragment under transmitted-light $(\mathrm{L})$ and polarized-light $(\mathrm{M})$, showing low birefringence of the granular basal layer. $1 \mathrm{~mm}$ horizontal scale applies for $A, C, L$ and $M ; 1 \mathrm{~mm}$ vertical scale for $E$ and $F$. 


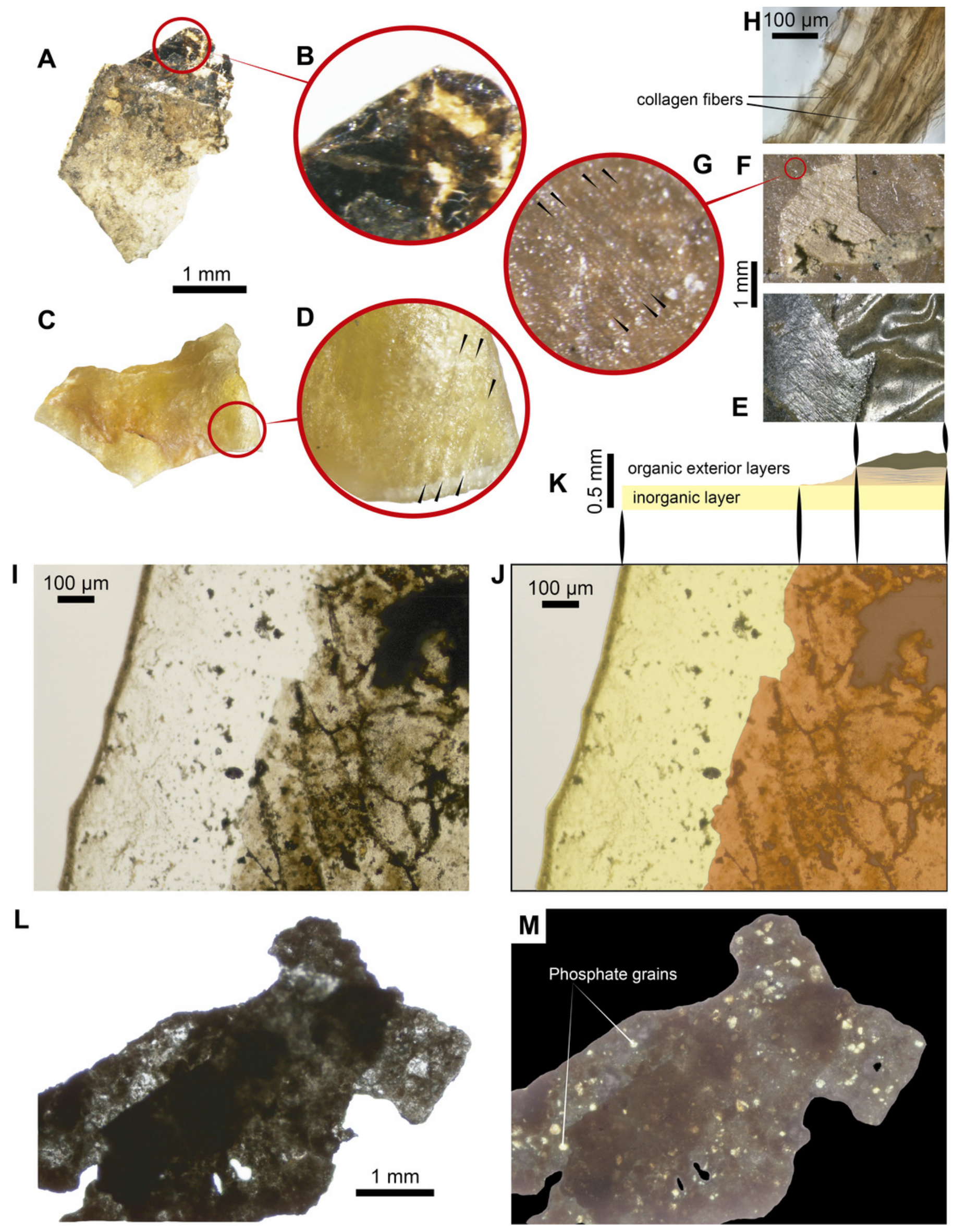




\section{Figure 4}

SEM-EDS micrographs and elemental composition analyses of an untreated and uncoated fragment of UR-CP-0001 'skin'

Figure 4. SEM-EDS micrographs and elemental composition analyses of an untreated and uncoated fragment of UR-CP-0001 'skin'. (A) Sample from UR-CP-0001 that contains 'skin' and infilling matrix. (B) detail of samples mounted over the stub. (C) SEM micrograph with point EDS analysis in the 'skin' region, showing the abundant content of carbon and nitrogen, with less occurrence of calcium and phosphorous. (D) SEM micrograph with point EDS analysis in the infilling matrix, showing absence of nitrogene, dominance of carbon and calcium instead. (E) SEM micrograph of the 'skin'-infilling matrix contact before apply the EDS analysis. (F) same micrograph as in (E) after EDS analysis, showing the extremely wrinkled organic surface of the 'skin', remaining intact the infilling matrix region. (G) Outline of the 'skin' organic and phosphatic layer, as well as the infilling matrix showed in e, which is the base of the elemental mapping. (H-L) Elemental mapping at 10kV of the 'skin' infilling matrix region showing dominance of carbon $(\mathrm{H})$ and oxygen $(\mathrm{I})$ at the organic region, and phosphorus $(K)$ at the boundary between the 'skin' and the infilling matrix; silicon $(J)$ is very scarce in both regions, and of calcium (L) is highly abundant in the infilling-matrix. 
A

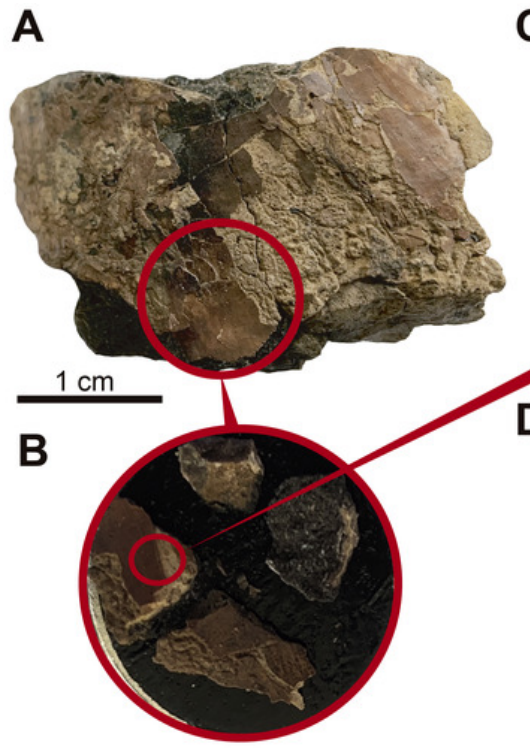

C
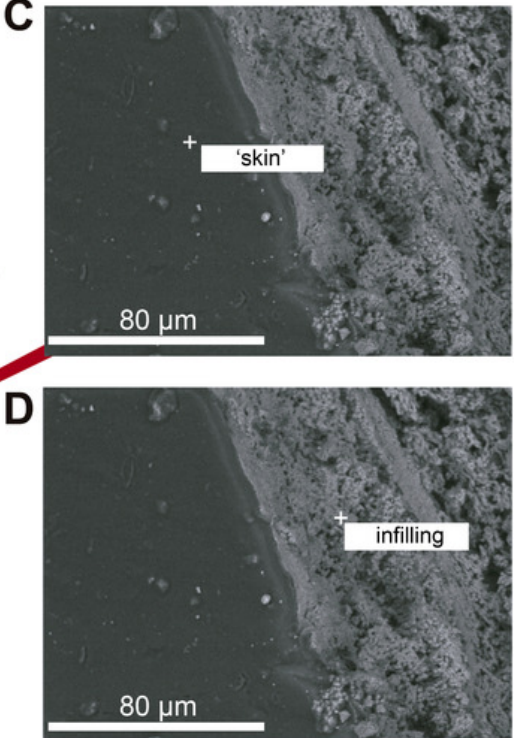

\begin{tabular}{l|lllll}
\hline Element & App & Intensity & Weight\% & Weight\% & Atomic\% \\
& Conc. & Corrn. & & Sigma & \\
C & 0.31 & 1.4480 & 51.14 & 1.97 & 61.73 \\
N & 0.01 & 0.1930 & 10.41 & 3.26 & 10.78 \\
O & 0.09 & 0.8443 & 24.00 & 1.09 & 21.75 \\
P & 0.03 & 1.4065 & 4.90 & 0.27 & 2.29 \\
Ca & 0.04 & 0.9313 & 9.55 & 0.49 & 3.45 \\
\hline Element & App & Intensity & Weight\% & Weight\% & Atomic\% \\
& Conc. & Corrn. & & Sigma & \\
C & 0.03 & 1.0459 & 26.26 & 2.11 & 38.43 \\
O & 0.04 & 0.7870 & 42.86 & 1.91 & 47.10 \\
Si & 0.00 & 1.1021 & 0.93 & 0.27 & 0.58 \\
P & 0.01 & 1.4874 & 5.88 & 0.53 & 3.34 \\
Ca & 0.03 & 1.0018 & 24.07 & 1.26 & 10.56 \\
\hline
\end{tabular}
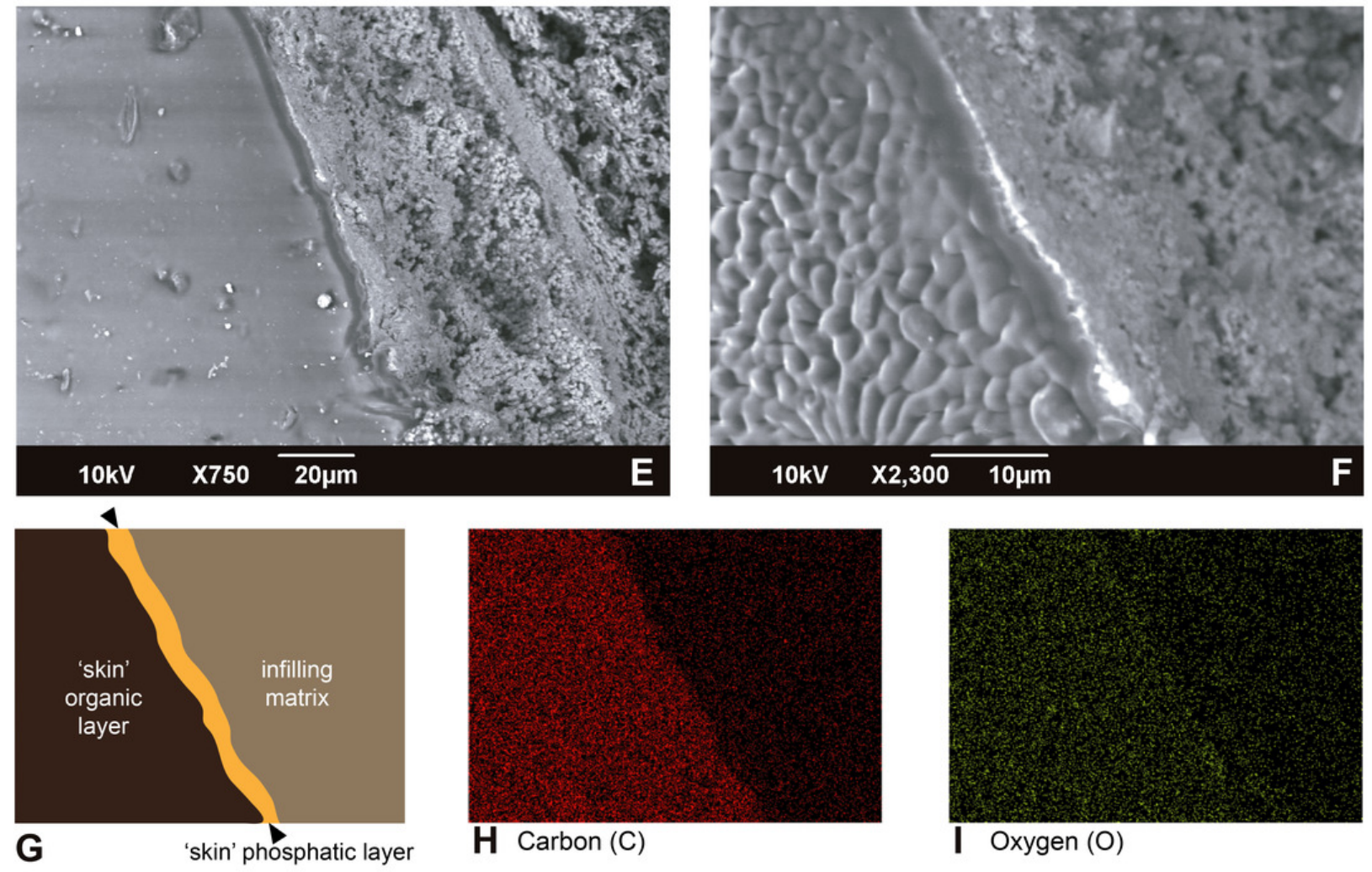

H Carbon (C)

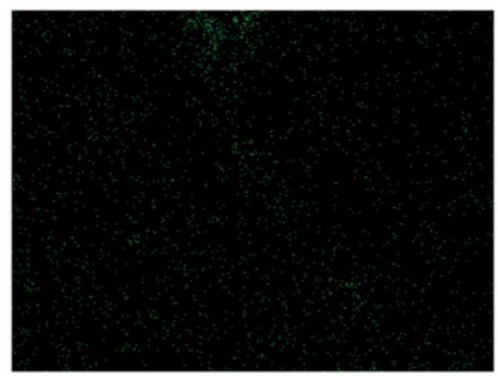

JSilicon (Si)

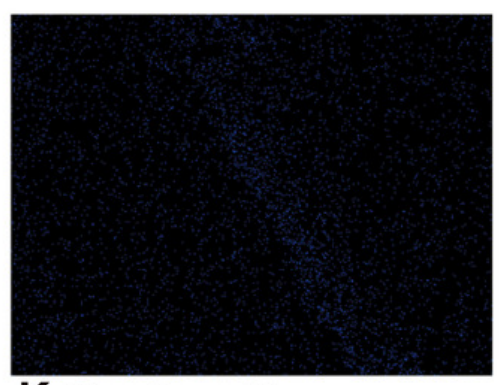

K Phosphorus (P)

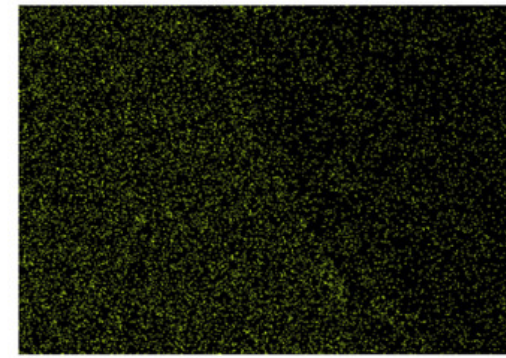

| Oxygen (O)

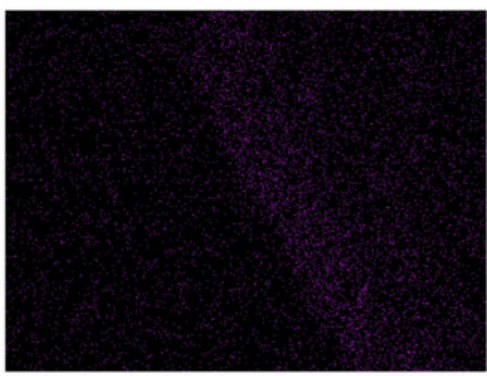

L Calcium (Ca) 


\section{Figure 5}

FTIR analyses of UR-CP-0001 and the extant Orechromis sp.

Figure 5. FTIR analyses of UR-CP-0001 and the extant Orechromis sp. (A) Composite FTIR spectra (absorbance vertical axis, wavenumber horizontal axis) of different samples:

Orechromis sp. (Mojarra fish) (dark blue line) with interpretation of typical proteinaceous compounds (Amide A, I, II, III, v(C=O), C-H stretch and a phosphate) with gray bands showing potential ranges based on Boatman et al. (2019); Kong \& Yu (2007); and Lee et al. (2017); an extant bacteria biofilms (black, yellow and purple lines) taken and redraw from Lee (et al. 2017) and Lindgren et al. (2011b); Vinctifer comptoni (orange line) from the Cretaceous of Brazil, taken and redraw from Sousa-Filho et al. (2016); UR-CP-0001 aspidorhynchid fossil fish 'skin' treated with EDTA (red line); treated with $\mathrm{HCl}$ (green line); untreated (light blue line); and UR-CP-0001 infilling matrix (brown line). (B) Skin sample from Orechromis sp. (Mojarra fish) used for the FTIR analysis and close-up of the skin sample analyzed from this specimen (C). (D) The region from which the 'skin' sample of UR-CP-0001 was taken, and a close-up of the 'skin' fragment after EDTA treatment under a transmitted light microscope (E). (F) URCP-0001 sample used for the untreated analysis and a close-up of the FTIR vibrational bands (red rectangle) in (A) after deconvolution (G). (H) UR-CP-0001 infilling matrix sample and how it was grinded using a sterilized mortar and pestle (I) and placed in the FTIR machine (J). 
A

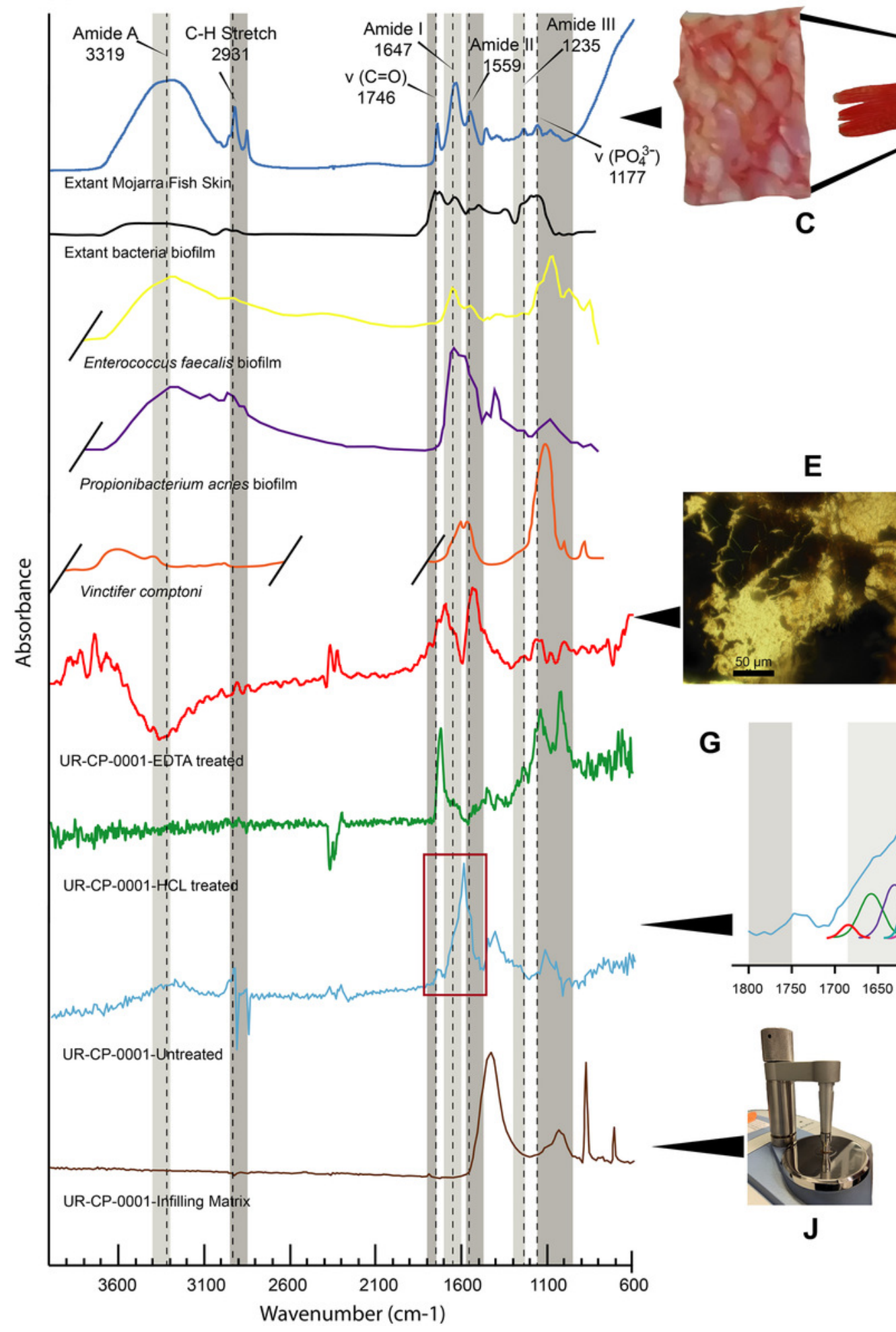

B

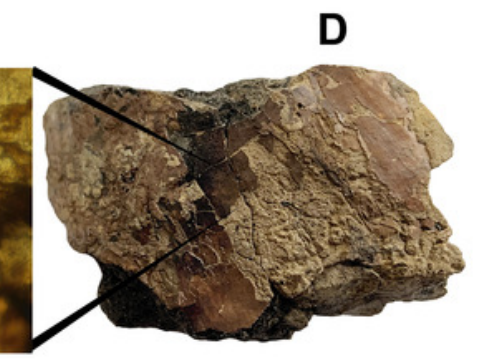

$\mathbf{F}$
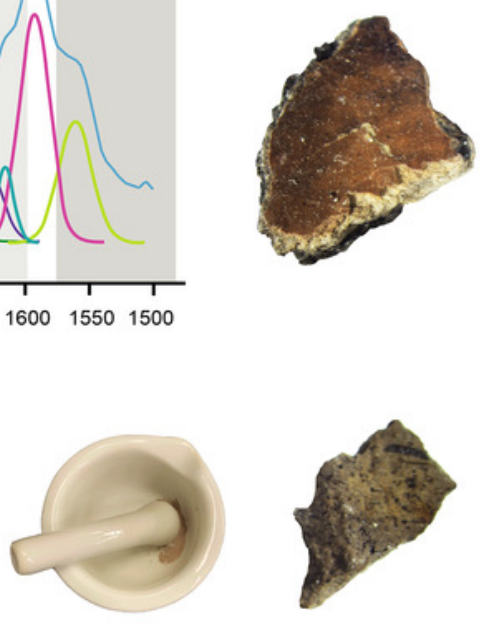

H 
Figure 6

ToF-SIMS analyses of UR-CP-0001 'skin'.

ToF-SIMS analyses of UR-CP-0001 'skin'. (A-B) Negative and Positive ion ToF-SIMS spectrum of UR-CP-0001 untreated sample (see circular photo of the sample), typical organic compounds occur in high intensities in both ions (raw data presented in Supplementary Data S1). (C-H) ToF-SIMS images showing the distribution of ions $\mathrm{CN}-(\mathrm{C}), \mathrm{CH} 4 \mathrm{~N}+(\mathrm{D}), \mathrm{C} 4 \mathrm{H} 8 \mathrm{~N}+$ (E), $\mathrm{CNO}-(\mathrm{F}), \mathrm{C} 2 \mathrm{H} 6 \mathrm{~N}+(\mathrm{G})$ and $\mathrm{C} 3 \mathrm{H} 6 \mathrm{~N}+(\mathrm{H})$. 

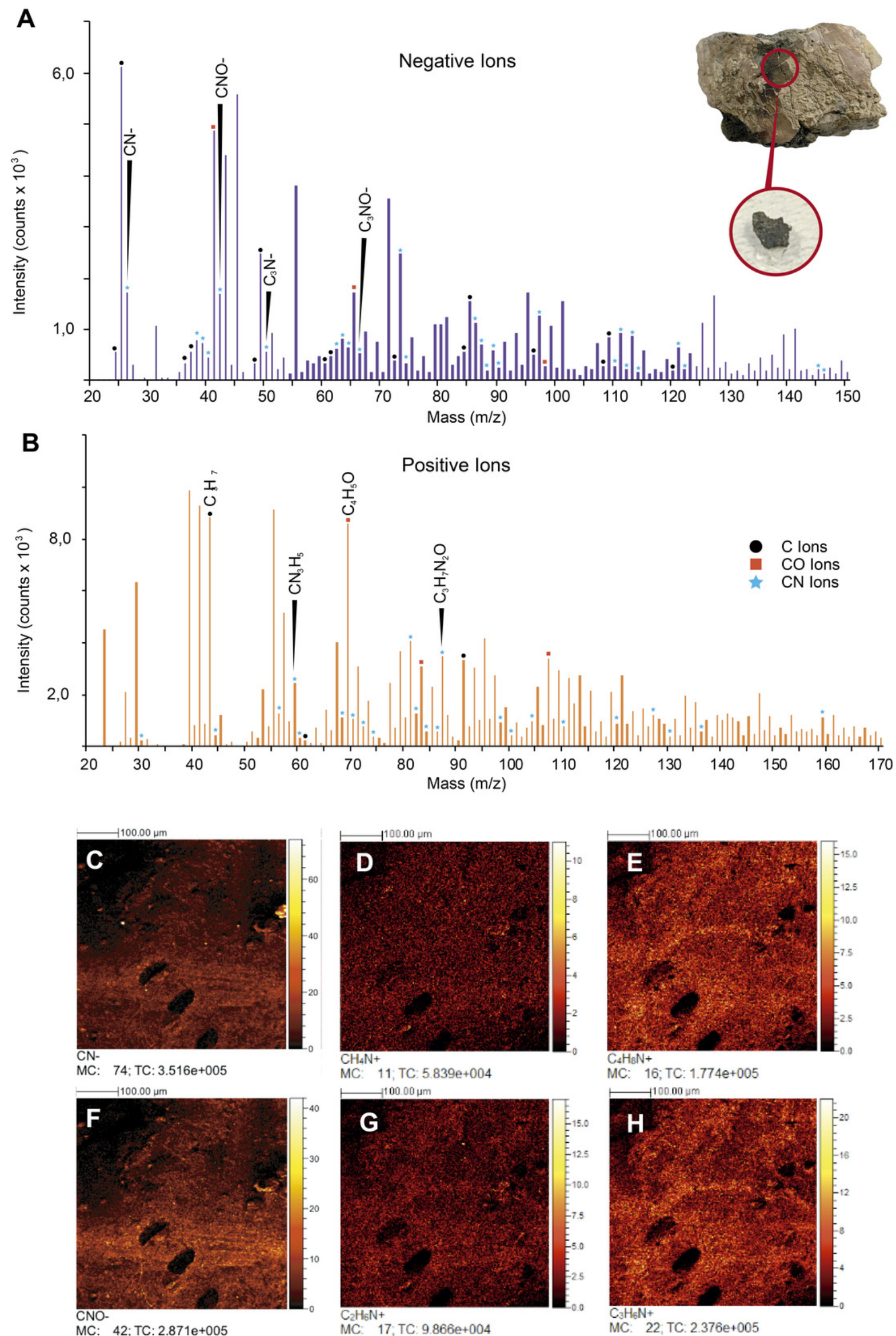

Peer) reviewing PDF | (2020:03:46405:2:0:NEW 9 Jun 2020) 


\section{Table $\mathbf{1}$ (on next page)}

Species tentative assignments and $\mathrm{m} / \mathrm{z}$ values

Table 1. Species tentative assignments and $\mathrm{m} / \mathrm{z}$ values for peaks in both positive and negative ToF-SIMS spectra from UR-CP-0001 and its possible organic source based on Samuel et al. (2001); Brüning et al. (2006); Lindgren et al. (2018); and Lindgren et al. (2012). 


\begin{tabular}{|c|c|c|c|}
\hline \multicolumn{4}{|c|}{ Tentative assignments and $\mathrm{m} / \mathrm{z}$ values for peaks in ToF-SIMS spectrum } \\
\hline $\begin{array}{c}\text { Tentative } \\
\text { assignment }\end{array}$ & Theoretical Mass & $\begin{array}{c}\text { Fossil sample } \\
\text { (UR-CP-0001) }\end{array}$ & $\begin{array}{c}\text { Associated organic } \\
\text { compound }\end{array}$ \\
\hline $\mathrm{CN}-$ & 26.00 & 25.997 & Melanin \\
\hline $\mathrm{CH}_{4} \mathrm{~N}$ & 30.036 & 29.998 & Glycine \\
\hline CNO- & 42.00 & 42.001 & Melanin \\
\hline $\mathrm{C}_{3} \mathrm{H}_{7}$ & 43.03 & 42.998 & Leucine \\
\hline $\mathrm{C}_{2} \mathrm{H}_{6} \mathrm{~N}$ & 44.053 & 43.999 & Alanine \\
\hline $\mathrm{C}_{3} \mathrm{~N}-$ & 50.00 & 50.000 & Melanin \\
\hline $\mathrm{C}_{3} \mathrm{H}_{6} \mathrm{~N}$ & 56.05 & 55.996 & Lysine \\
\hline $\mathrm{CN}_{3} \mathrm{H}_{5}$ & 59.05 & 59.001 & Arginine \\
\hline $\mathrm{C}_{2} \mathrm{H}_{6} \mathrm{NO}$ & 60.045 & 59.999 & Serine \\
\hline $\mathrm{C}_{2} \mathrm{H}_{5} \mathrm{~S}$ & 61.01 & 60.998 & Methionine \\
\hline $\mathrm{C}_{3} \mathrm{NO}-$ & 66.00 & 65.996 & Melanin \\
\hline $\mathrm{C}_{4} \mathrm{H}_{6} \mathrm{~N}$ & 68.05 & 67.996 & Proline \\
\hline $\mathrm{C}_{4} \mathrm{H}_{5} \mathrm{O}$ & 69.03 & 68.998 & Threonine \\
\hline $\mathrm{C}_{4} \mathrm{H}_{8} \mathrm{~N} / \mathrm{C}_{3} \mathrm{H}_{4} \mathrm{NO}$ & 70.068 & 70.000 & Proline \\
\hline $\mathrm{C}_{4} \mathrm{H}_{10} \mathrm{~N}$ & 72.084 & 71.997 & Valine \\
\hline $\mathrm{C}_{3} \mathrm{H}_{8} \mathrm{NO}$ & 74.063 & 73.998 & Threonine \\
\hline $\mathrm{C}_{5} \mathrm{~N}-/ \mathrm{C}_{2} \mathrm{H}_{2} \mathrm{O}_{3}$ & 74.00 & 74.000 & Melanin \\
\hline $\mathrm{C}_{4} \mathrm{H}_{5} \mathrm{~N}_{2}$ & 81.04 & 80.996 & Histidine \\
\hline $\mathrm{C}_{4} \mathrm{H}_{6} \mathrm{~N}_{2}$ & 82.05 & 81.998 & Histidine \\
\hline $\mathrm{C}_{5} \mathrm{H}_{7} \mathrm{O}$ & 83.09 & 83.000 & Valine \\
\hline $\mathrm{C}_{5} \mathrm{H}_{10} \mathrm{~N}$ & 84.085 & 84.003 & Lysine \\
\hline $\mathrm{C}_{5} \mathrm{H}_{12} \mathrm{~N} / \mathrm{C}_{4} \mathrm{H}_{8} \mathrm{NO}$ & $86,064 / 86,101$ & 86.002 & Hydroxyproline/Leucine \\
\hline $\mathrm{C}_{3} \mathrm{H}_{7} \mathrm{~N}_{2} \mathrm{O}$ & 87.05 & 86.999 & Aspargine \\
\hline $\mathrm{C}_{7} \mathrm{H}_{7}$ & 91.05 & 90.998 & Phenylalanine \\
\hline $\mathrm{C}_{4} \mathrm{H}_{4} \mathrm{NO}_{2}$ & 98.02 & 97.999 & Aspargine \\
\hline $\mathrm{C}_{4} \mathrm{H}_{10} \mathrm{~N}_{3}$ & 100.088 & 99.999 & Arginine \\
\hline $\mathrm{C}_{4} \mathrm{H}_{10} \mathrm{NS}$ & 104.05 & 104.002 & Methionine \\
\hline $\mathrm{C}_{7} \mathrm{H}_{7} \mathrm{O}$ & 107.048 & 106.999 & Tyrosine \\
\hline $\mathrm{C}_{8} \mathrm{~N} / \mathrm{C}_{9} \mathrm{H}_{2}$ & 110.075 & 109.999 & Histidine \\
\hline $\mathrm{C}_{8} \mathrm{H}_{10} \mathrm{~N}$ & 120.084 & 120.000 & Phenylalanine \\
\hline $\mathrm{C}_{5} \mathrm{H}_{11} \mathrm{~N}_{4}$ & 127.1 & 126.997 & Arginine \\
\hline $\mathrm{C}_{9} \mathrm{H}_{8} \mathrm{~N}$ & 130.068 & 130.003 & Tryptophan \\
\hline $\mathrm{C}_{8} \mathrm{H}_{10} \mathrm{NO}$ & 136.082 & 136.005 & Tyrosine \\
\hline $\mathrm{C}_{10} \mathrm{H}_{11} \mathrm{~N}_{2}$ & 159.04 & 159.00 & Tryptophan \\
\hline
\end{tabular}

